Sains Malaysiana 46(8)(2017): 1323-1331

http://dx.doi.org/10.17576/jsm-2017-4608-19

\title{
Control of Microbiologically Influenced Corrosion using Ultraviolet Radiation
}

(Kawalan Terhadap Kakisan Dipengaruhi Mikrobiologi Menggunakan Radiasi Ultralembayung)

\author{
AKrima Abu BaKar, MuHAmmad Khairool Fahmy MoHd Ali, NorhaZILAn Md. NoOR*, Nordin YaHAYA, \\ MARDHIAH ISMAIL \& AHMAD SAFUAN A. RASHID
}

\begin{abstract}
Baram Delta Operation had been producing oil and gas since 1960's and serious pipelines failure was reported in the year of 2005. The final investigation has concluded that one of the species of bacteria that has been identified to cause microbiologically influenced corrosion, specifically known as sulfate reducing bacteria (SRB) was found to be one of the potential contributing factors to the incidents. This work investigates the potential use of ultraviolet (UV) radiation to inhibit the SRB consortium that was cultivated from the crude oil in one of the main trunk lines at Baram Delta Operation, Sarawak, Malaysia. The impact of UV exposure to bio-corrosion conditions on carbon steel coupon in certain samples for 28 days was discussed in this study. The samples were exposed to UV radiation based on variations of parameters, namely: time of UV exposure; and power of UV lamp. The significant changes on the amount of turbidity reading and metal loss of the steel coupon were recorded before and after experiment. The results showed that SRB growth has reduced rapidly for almost $90 \%$ after the UV exposure for both parameters as compared to the abiotic samples. Metal loss values were also decreased in certain exposure condition. Additionally, field emission scanning electron microscopy (FESEM) coupled with energy dispersive spectroscopy (EDS) was performed to observe the biofilm layer formed on the metal surface after its exposure to SRB. The evidence suggested that the efficiency of UV treatment against SRB growth could be influenced by the particular factors studied.
\end{abstract}

Keywords: Biocorrosion; sulfate reducing bacteria (SRB); ultraviolet radiation

\section{ABSTRAK}

Operasi Delta Baram (BDO) telah beroperasi bagi menghasilkan pengeluaran minyak dan gas semenjak tahun 1960 dan sistem saluran paipnya telah dilaporkan mengalami kegagalan serius pada tahun 2005. Kesimpulan daripada siasatan akhir mendapati salah satu daripada spesies bakteria telah dikenal pasti menyebabkan biokakisan, dikenali sebagai bakteria penurun sulfat (SRB) merupakan faktor penyumbang kepada insiden tersebut. Kajian ini menganalisa potensi penggunaan sinaran ultralembayung (UV) sebagai perencat kepada pertumbuhan SRB konsortium yang telah diasingkan daripada minyak mentah di salah satu saluran paip utama di BDO, Sarawak, Malaysia. Kesan sinaran UV terhadap pertumbuhan biokakisan pada kupon keluli karbon telah dikaji selama 28 hari dan keputusannya dibincangkan. Sampel dikaji berdasarkan parameter yang berbeza, iaitu: masa pendedahan kepada sinaran UV; dan nilai kuasa lampu UV. Sampel telah didedahkan kepada sinaran UV berdasarkan variasi parameter, iaitu: masa pendedahan UV; dan kuasa lampu UV. Nilai bacaan kekeruhan dan kehilangan logam kupon keluli diambil sebelum dan selepas pendedahan. Hasil kajian menunjukkan bahawa pertumbuhan SRB telah berkurang dengan pesat menghampiri nilai $90 \%$ selepas pendedahan UV dijalankan untuk kedua-dua parameter berbanding sampel abiotik. Nilai pengurangan logam juga telah menurun dalam keadaan pendedahan UV yang tertentu. Perubahan terhadap nilai bacaan kekeruhan sampel dan kehilangan berat kupon keluli dicatat. Selain itu, ujian mikroskopi pancaran medan elektron imbasan (FESEM) dan ujian spektroskopi tenaga serakan (EDS) juga dijalankan untuk melihat lapisan biofilem yang terbentuk di atas permukaan logam selepas pendedahannya kepada aktiviti SRB. Hasil kajian mendapati bahawa kecekapan rawatan UV terhadap pertumbuhan SRB boleh dipengaruhi oleh faktor-faktor tertentu yang dikaji.

Kata kunci: Bakteria penurun sulfat; biokakisan; sinaran ultralembayung

\section{INTRODUCTION}

Microbiologically influenced corrosion (MIC) such as sulfate reducing bacteria (SRB) in biofilm consortia has signalled the role of this particular bacterium in the process of corrosion in pipelines and seawater injection systems (AlAbbas 2013; Almahamedh et al. 2011; Comanescu et al. 2012; Maxwell \& Campbell 2006). It is well-known that
MIC can oxidize a wide variety of chemicals and use them as nutrient sources and enhance their proliferation. SRB are anaerobic microorganisms release sulphides and gas phase $\mathrm{H}_{2} \mathrm{~S}$ from the obtained energy by dissimilatory reduction of sulphate (Chang et al. 2014). According to Sarioĝlu et al. (1997), the petroleum production environment is particularly suitable for the activities of SRB because it 
handles large volumes of de-aerated water. Microbial activity in any environment occurs in the presence of water, a carbon source, an electron donor and an electron acceptor, all of which can be present in oil pipelines (Almahamedh et al. 2011). Jack et al. (1996) reported in one survey, MIC was responsible for $27 \%$ of the corrosion deposits on the pipe exterior of Nova Gas Transmission Ltd. (Calgary, Alberta) lines. Over the years, oil and gas production has undergone technologies evolution in products processing, inspection, monitoring and other aspect. Despite that, pipelines is still remains as the most efficient, energy saving and cost effective transportation to convey the oil and gas products from oilfield well to processing tank and lastly to public market (Beavers \& Thompson 2006). Hence, pipelines need to be preserved as long as possible to avoid high costing in replacement and interruption of products supplies.

Although several new mitigation methods have started to emerge such as adding nitrate to promote the growth of nitrate reducers that can outcompete SRB for nutrients (Chang et al. 2015; Chintan et al. 2005), the recommended mitigation by most companies is still focused on biocides consumptions. Biocides injection is the typical technique to mitigate MIC but it is a toxic chemicals that must be handled carefully, cost ineffective and could cause environmental pollutions (Maxwell 2005). Furthermore, in some countries, biocides application has to meet stringent regulations. Insufficient quantity of biocides could lower the efficiency of bacteria disinfection (Cheung et al. 1995) and it must be rotated on a regular scheduled basis to be effective. The process of mitigating MIC by using biocides also requires all operations to be stopped briefly and this is costly and wastes a lot of time (Wang et al. 2005). In addition, environmental concerns associated with chemical disinfection have also led to the transition from traditional chemical disinfection to mechanical procedures (Lawal et al. 2010).

In tandem with this, ultraviolet (UV) is found to be as one of the potential substances to function as a non-physical inhibitor (Javaherdashti 2008; Wang et al. 2005). UV radiation is an established technology and it is a common method to disinfect bacteria in water treatment facilities and has also been used as a sterilisation material in many industries. Most UV radiation is designed for disinfection or to control the bacteria populations (Maxwell 2005). In the book, MIC - An engineering insight written by Javaherdasti (2008), UV was defined as another method that may have good efficiency and has become a promising method against soft biofilms. Key target of UV induced damage is deoxyribonucleic acid (DNA) in a variety of organisms, ranging from bacteria and human. Due to this damage, the bacteria cannot duplicate and hence it exterminates bacteria colonies (Mckinney \& Pruden 2012). Previous studies of UV disinfection in mitigating the MIC in oil and gas system has proven to be an effective method and eliminate $99 \%$ reduction in bacteria present in the water (Clark et al. 1984; Gloe et al. 2010; Lawal et al. 2010; Wang et al. 2005). However, the research are still hovering in many argument arise on the MIC role in deterioration of engineering material and the lack of the optimum performance of UV.

In 2005, a major pipeline failure took place on one of the four main import trunk lines into Miri Crude Oil Terminal (МСОТ). The operation system is name as Baram Delta Operation (BDO) systems and consists of 9 oilfields. Investigations of pipelines systems failure done reported that MIC, particularly SRB was a potential contributing factor to the failure (Allison et al. 2008). Current MIC treatment system in BDO is by the combination of scheduled pigging and biocides injection. However, the incident has indicated that the treatment system implemented is not adequate in controlling the MIC impact in the pipelines system. Thus, this research was designed to explore the potential of UV radiation to mitigate the SRB cultivated from one of the main trunk line in BDO's crude oil field samples upon several parameters. Solid evidence on the performance need to be investigated to ensure that UV radiation could be viable option for mitigating MIC activity and simultaneously minimize the biocorrosion impact triggered by MIC.

\section{EXPERIMENTAL DETAILS}

\section{MICROORGANISM AND MEDIA}

The marine SRB consortium used in this study was cultivated from crude oil samples obtained from one of the main trunk line of BDO, Sarawak, Malaysia. The crude oil samples were collected and bottled from Miri Crude Oil Terminal (МCOT) as depicted in Figure 1. The sample was originated from Baram oilfield. SRB kits (Sani Check, Biosan Lab. Inc.,USA) were used to test SRB presence in the crude oil samples. Appearance of black colour in the particular samples, indicated that the SRB was presence (Little \& Lee 2009). The SRB was cultivated in three different growth media: Modified Baar's (Broth 1249), Postgate B and Postgate C to

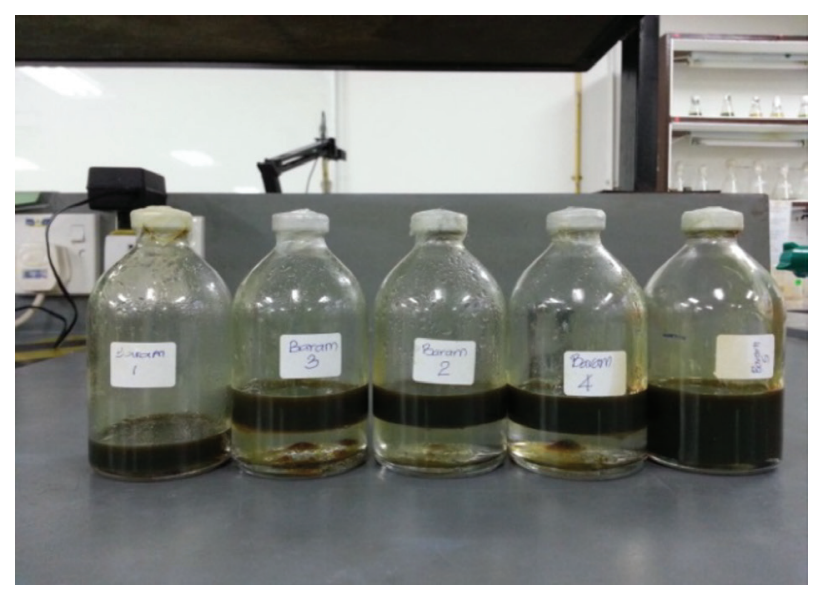

FIGURE 1. Sample of raw crude oil collected from Baram oilfield 
determine the preferable growth medium for them to grow and proliferate rapidly. As shown in Figure 2, the result showed that the Modified Baar's medium (Broth 1249) boosted the SRB growth compared to others media. Table 1 listed the chemical compositions of the modified Baar's medium. All the experimental equipment and medium were then autoclaved at $121^{\circ} \mathrm{C}$ for $15-20 \mathrm{~min}$ to avoid any risk of bacterial contamination.

Ferrous ammonium sulfate $\left(\mathrm{Fe}\left(\mathrm{NH}_{4}\right)_{2}\left(\mathrm{SO}_{4}\right)_{2}\right)$ with 25 ppm concentration was filtered followed by the addition of sterile to the medium. The media was sparged with oxygen-free nitrogen after the prior inoculation of SRB; 2 $\mathrm{mL}$ of the cultivated medium with SRB was added to 100 $\mathrm{mL}$ fresh growth medium and then incubated for 3 days in an anaerobic condition sealed with butyl rubber stoppers. SRB should grow in the range of 4 to 9.5 according to certain SRB genus (Barton \& Hamilton 2010). Based on the pilot test, $\mathrm{pH} 8.5$ and temperature $37^{\circ} \mathrm{C}$ was identified as the optimum environment for the growth of SRB in this particular area.

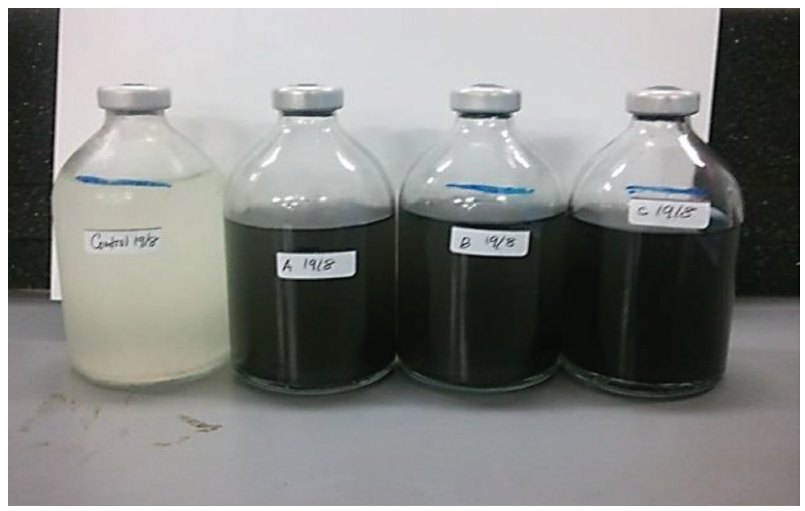

FIGURE 2. Baram oilfield's raw crude oil was cultivated in Modified Baar's medium

TABLE 1. Chemical composition of the Modified Baar's medium

\begin{tabular}{lc}
\hline Chemical reagents & Compositions $(\mathrm{g} / \mathrm{L})$ \\
\hline $\mathrm{MgSO}_{4}$ & 2.0 \\
Sodium citrate & 5.0 \\
$\mathrm{CaSO}_{4}$ & 1.0 \\
$\mathrm{NH}_{4} \mathrm{Cl}, 1.0 \mathrm{~g}$ & 1.0 \\
$\mathrm{~K}_{2} \mathrm{HPO}_{4}$ & 0.5 \\
Sodium lactate $_{\text {Yeast extract, }}$ & 3.5 \\
$\mathrm{Fe}\left(\mathrm{NH}_{4}\right)_{2}\left(\mathrm{SO}_{4}\right)_{2}$, & 1.0 \\
\hline
\end{tabular}

\section{MATERIALS}

The material used in this study was a carbon steel coupon API 5L grade X-70 gathered from the actual pipeline section. Samples were cut into $10 \times 20 \times 5 \mathrm{~mm}$ dimension to fit the anaerobic vials opening. The test coupons were polished with 100 grit $\mathrm{SiC}$ paper. It was also cleaned and dried with acetone (purity 99.5\%) to remove all forms of dirt, grease and small SiC particle on the coupon surface. The cleaned and dried coupons were then coated with heavy duty protective coatings (Zinc Chromate Primer, Nippon Paint) leaving only one surface exposed to the medium in anaerobic vials. The coupons were then dried overnight in an oven at $37^{\circ} \mathrm{C}$. Prior to use, the exposed area of the coupon was polished again with series of $\mathrm{SiC}$ paper grade 320,600 and 800 , followed by acetone degreasing (purity 99.5\%) (Abdullah et al. 2014; Ismail et al. 2014).

\section{LABORATORY TEST}

\section{BACTERIA ENUMERATION}

A spectrophotometer DR 6000 (HACH, US) was used to determine the optical density (OD) of the assigned broth culture at $600 \mathrm{~nm}$ wavelength in this study. The medium was diluted at one time dilution before the turbidity measurement was taken. The absorbance values were recorded on the retrieval days. SRB were found to have survived in the oxygen exposure of up to $72 \mathrm{~h}$ (Larry et al. 2010), this proved that these enumeration methods could be done under the aerobic condition within certain time limitation. The black colour of the medium observed in the samples indicated SRB's growth within 2 to 3 days after the injection of the SRB seed into the media. High turbidity reading signified the presence of higher SRB population. Therefore, in this experiment, turbidity was chosen as the SRB growth indicator method.

\section{ULTRAVIOLET TREATMENT}

Previous researches reported that UV radiation with spectral region (100-280 $\mathrm{nm}$ ) has the ability to cause substantial biological damage and thus makes a convenient experiment tool (Ana et al. 2013). According to Wang et al. (2005), UV radiation that triggers the most effective germicidal activity at its peak is $254 \mathrm{~nm}$; hence this figure was fixed upon all factorials in this study. Samples initial condition were labelled as biotic and abiotic which represent the samples exposed to UV in different parameters and samples with no exposure to UV, respectively. The treatment was performed at day-3 prior to the injection of SRB seeds. Figure 3 displays the UV exposure condition in the laminar flow. Biotic samples were then exposed to two factors, which were time exposure and the different power of UV lamp. The ranges of the time exposures were 3,30 and $60 \mathrm{~min}$. Moreover the power of the UV lamp consists of 10 and 14 watts as depicted in Figure 4. The turbidity of the SRB was taken on a weekly basis using spectrophotometer DR6000. Weight of steel coupons was recorded before and after the experiment on retrieval day (days 7, 14,21 and 28).

\section{METAL LOSS TEST}

Metal loss test was carried out in the anaerobic vials containing sterile Modified Baar's media. During the test, coupons were retrieved from anaerobic vials based 


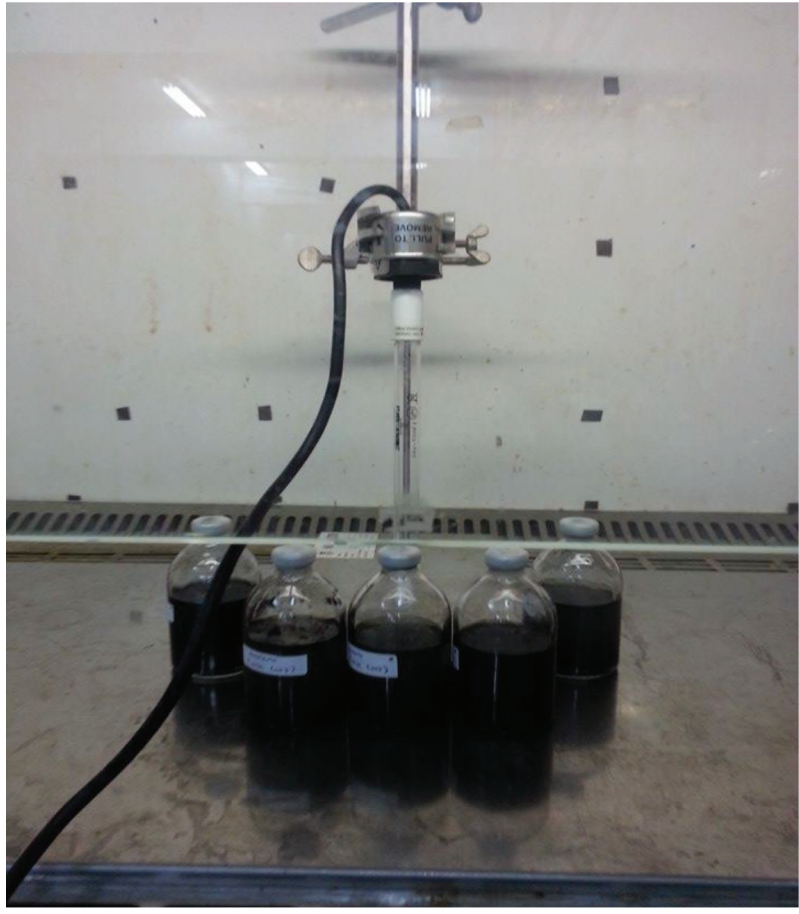

FIGURE 3. UV exposure arrangement

on weekly basis (days 7, 14, 21 and 28). The retrieved coupons were cleaned with Clarke's solution (mixture of HCL and mineral solution) to remove all forms of dirt and left to dry. The coupon weight before and after immersion in the medium was recorded systematically. Metal loss was determined by using the following formula (Nordin et al. 2011; Norhazilan et al. 2012):

$$
\operatorname{Metal} \operatorname{loss}(\mathrm{W})=\left(\mathrm{W}_{\mathrm{o}}-\mathrm{W}_{\mathrm{a}}\right) \text {, }
$$

where $\mathrm{W}_{\mathrm{o}}$ is the initial weight of coupon $(\mathrm{g})$; and $\mathrm{W}_{\mathrm{a}}$ is the final weight of coupon $(\mathrm{g})$.

The overall experimental overview is shown in Figure 5 .

\section{RESULTS AND DISCUSSION}

\section{PREFERABLE MEDIUM}

Figure 6 provides the preliminary experimental data on the growth of the SRB cultivated in different media from the Baram site for a week. This laboratory experiment was done to observe the preferable media that could promote the particular bacteria growth. Three (3) different media were selected, which were Modified Baar's, Postage B and Postgate $\mathrm{C}$ to cultivate the SRB. From the graph pattern, it is apparent that turbidity reading illustrates a higher growth rate for the SRB consortium present in modified Baar's medium during the seven (7) days of cultivation period. However, the growth of SRB was found to have steadily increased in Postgate B and Postgate C medium but at very slow rate. Turbidity data at day-7 for Modified

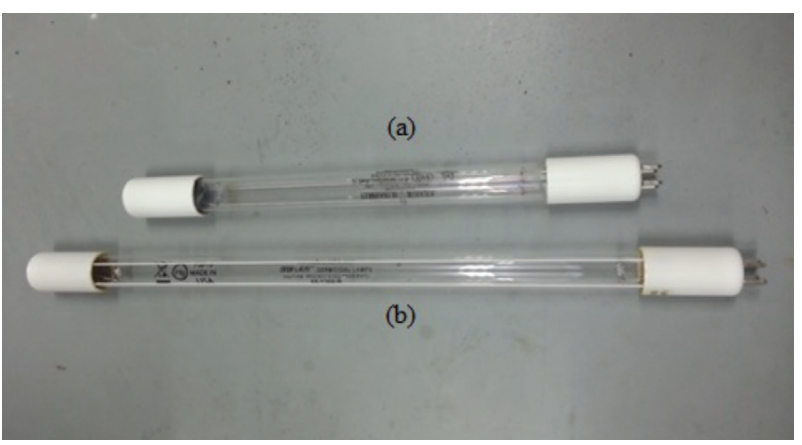

FIGURE 4. UV Lamp (a) 10 watts and (b) 14 watts

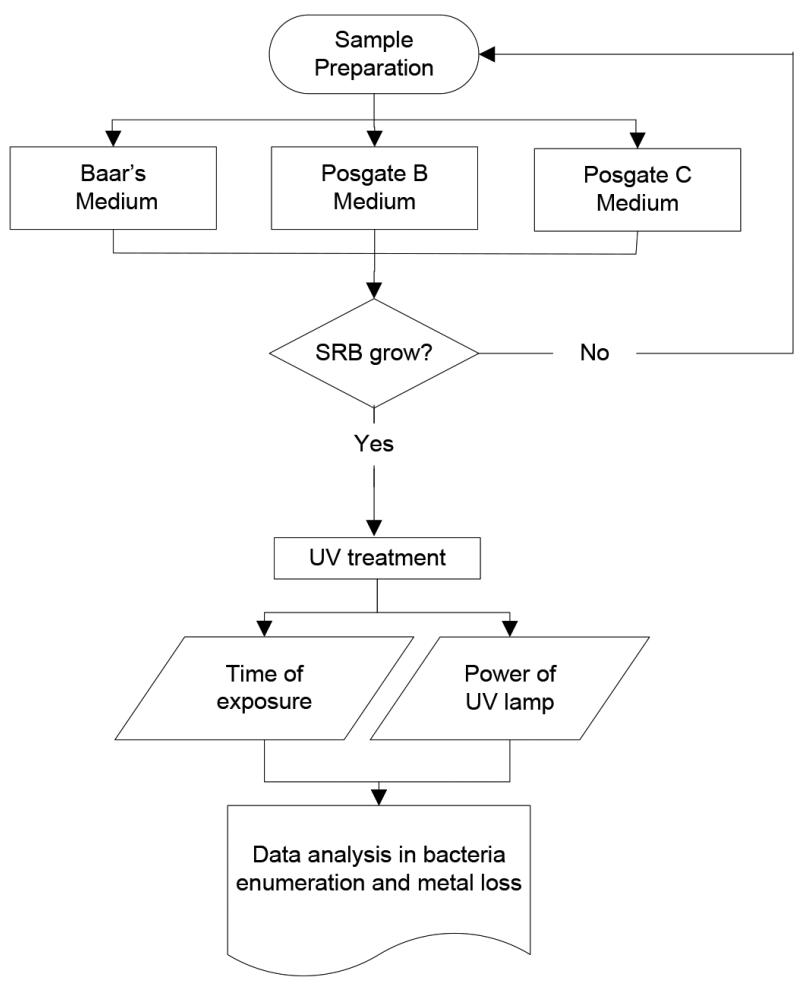

FIGURE 5. Overall experimental overview

Baars was recorded to be at the highest point, $0.621 \mathrm{Abs}$, as compared to $0.160 \mathrm{Abs}$ in Postgate $\mathrm{B}$ and $0.246 \mathrm{Abs}$ in Postgate C media.

Even though the same carbon source was used in all the respective three mediums, the different strains of SRB had their own preferable medium to grow. These results showed that each chemical composition in the medium indicated different effects on the growth of bacteria. Moreover, the presence of iron (Fe) in the medium is an essential component that was responsible for assisting the microbial activity of SRB. Dennis and Julia (2014), stated that in MIC, iron sulfides $(\mathrm{FeS})$ is one of the significant characteristics in products to promote bacteria growth.

FESEM was performed on the steel coupon for abiotic system before the UV treatment was conducted to observe the layer formation of SRB biofilm. Figure 7(a) and 7(b) presents the FESEM image under $5.00 \times$ magnification. 


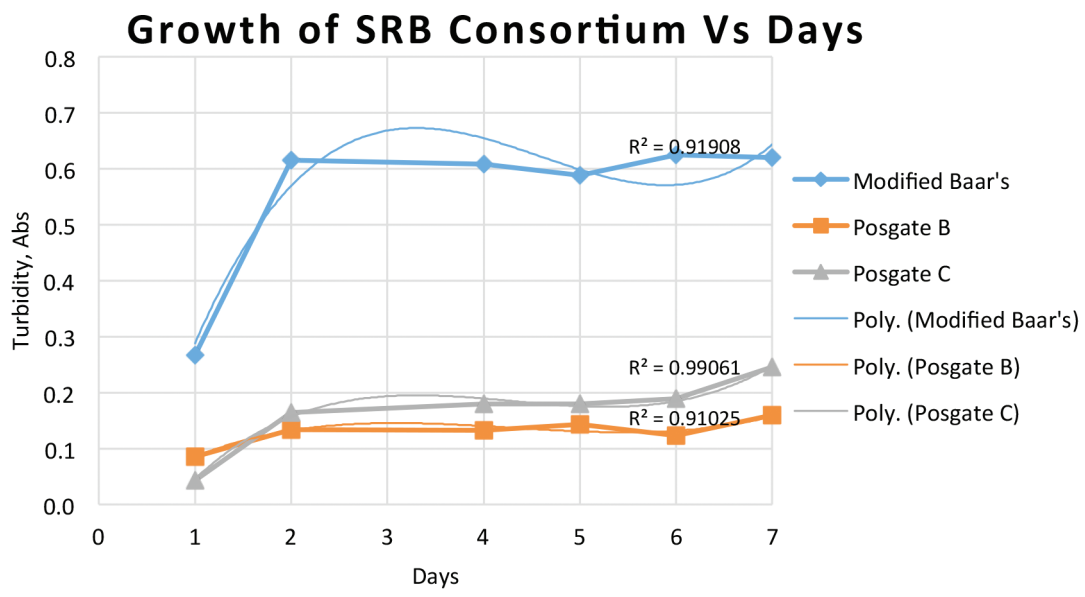

FIGURE 6. Growth pattern of SRB consortium in a particular media

a)

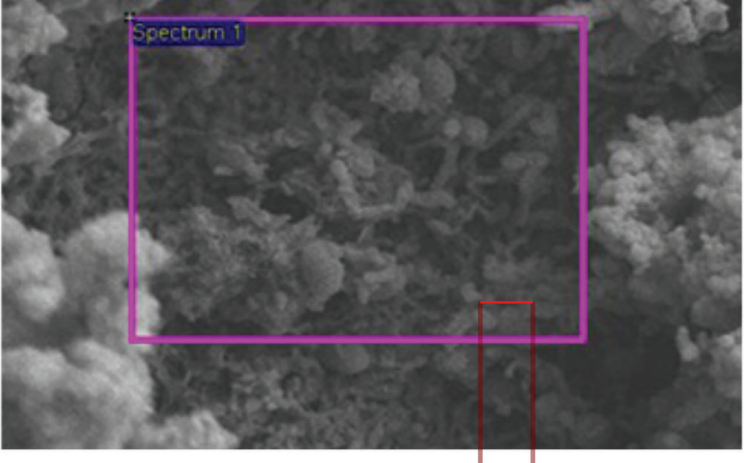

b)

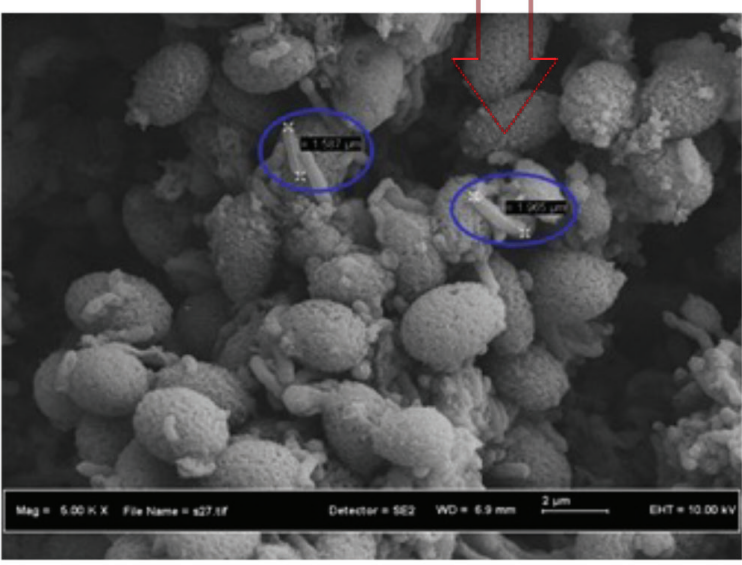

c)

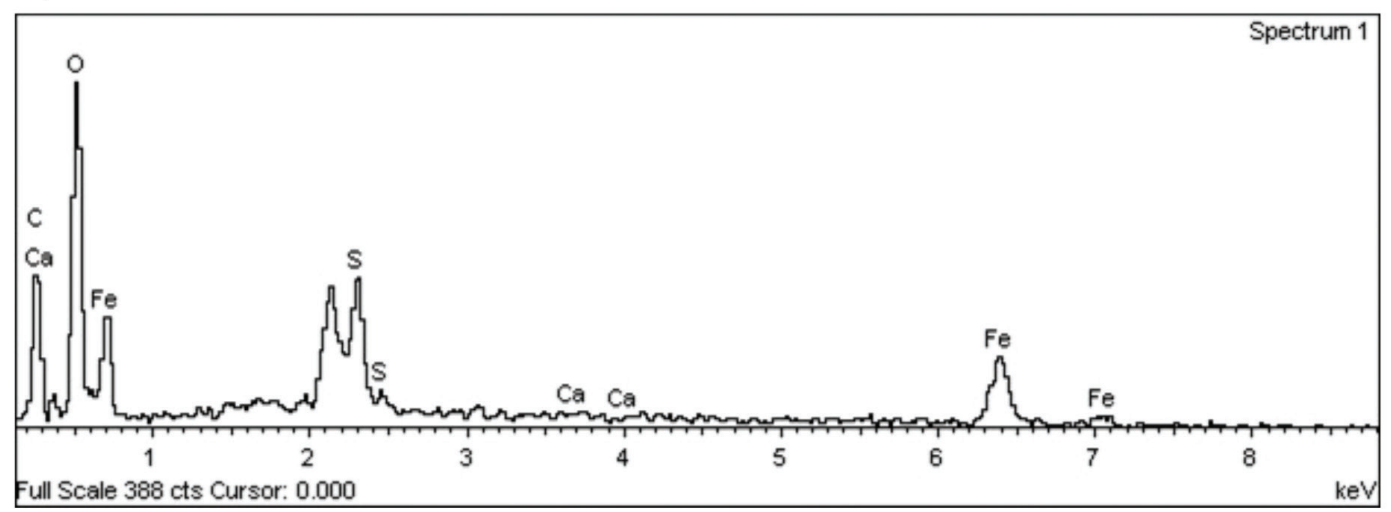

FIGURE 7. FESEM and EDS analysis for abiotic system $(a, b)$ FESEM image on the carbon steel coupon surface c) EDS analysis corresponding to Figure 7(a) 
The biofilm, cell, spores and corrosion production were graphically traced on the coupon surfaces after 21 days it was immersed in the media containing SRB. The substrate of the steel was scarcely visible since it was covered with a porous black layer. The black layer was the evidence of SRB metabolism activities that had happened on the metal surface. The image shows the morphology of SRB consortium cells which is in rod-shaped, with different length and sizes.

MIC started with the biofilm formation on the metal surface. SRB cells attached to the coupon surface, grew, reproduced and produced an extracellular polymer substance (EPS). According to previous research reports, normally the EPS and corrosion product occupy $75-95 \%$ of biofilms volume, while $5-25 \%$ is occupied by the cells (Alabbas et al. 2012). EDS analysis displaying the chemical characteristic of the developed biofilm on the carbon steel coupon is shown in Figure 7(c). The evidence of the enrichment of sulphur and ferum composition was observed in the analysis result. Sulphur is known as microbial nutrient and it has been reported that it could induce the carbon steel susceptibility to MIC (Hamzah et al. 2013), hence promoted sites for bacterial colonisation (Hamzah et al. 2013; Javaherdasti 2008).

Figure 8 displays the FESEM image for abiotic system. The images were captured after the coupon was cleaned with Clarke's solution. The impact of SRB consortium metabolism is clearly visible in the image, indicating that pitting corrosion had occurred on the coupon surface as shown in Figure 8. SRB consortium metabolism activities have the potential to induce higher concentrations of sulphur, ferum-based compounds and they generally could enhance the corrosion process. Pitting holes could also resemble actual bacterial cell morphologies and could be attributed to the potential direct contact between individual cells and steel surface (Alabbas et al.2012). The images further show that the layers of biofilms produced anaerobic condition and created differential aeration cells on the coupon surface. In line with these phenomena, the anaerobic area became anodic and the steel surface that was enriched in oxygen became cathodic. Thus, electrochemical cells were triggered, resulting in the pitting corrosion (Hamzah et al. 2013). Additionally, the rate of pitting, pit depth growth and the rate of bacterial metabolism showed a correlation with the rate of anaerobic bacteria nutrient supply (Melchers \& Jeffrey 2008).

\section{TIME FACTORIAL}

The laboratory experiment was designed to investigate the UV efficiency on SRB growth and metal loss of the steel coupon. One-factor-at-a-time (OFAT) procedure was performed to analyse the factorial experiments in improving the performance of UV radiation against the time of UV exposure and power of UV lamps. OFAT requires only one variable at a time while others parameters are rigid in investigating the influence of certain factor without any interaction effect (Clements 1995). Subsequently, a 10 watt UV light was exposed to the media at different time durations (biotic condition) to exterminate the SRB colonies, except those in the abiotic samples at day-3 of incubation. Figure 9 illustrates the pattern of SRB growth after the UV treatment. The data in the graph clearly shows that turbidity value of all the biotic samples decreased after the UV treatment except for the abiotic samples. The growth of SRB in abiotic samples steadily increased throughout the 28 days of incubation. However, the exposure to UV radiation in various time segments resulted in a similar effect since there were no significant differences on the growth of all the biotic samples on day-14 to day-28. Different readings of bacteria growth's turbidity between abiotic condition and the triple biotic conditions were within the range of 0.6882 abs to 0.611 abs on day-28. These suggest that the variation in the exposure time of UV radiation did not influence the SRB growth rate in biotic condition.

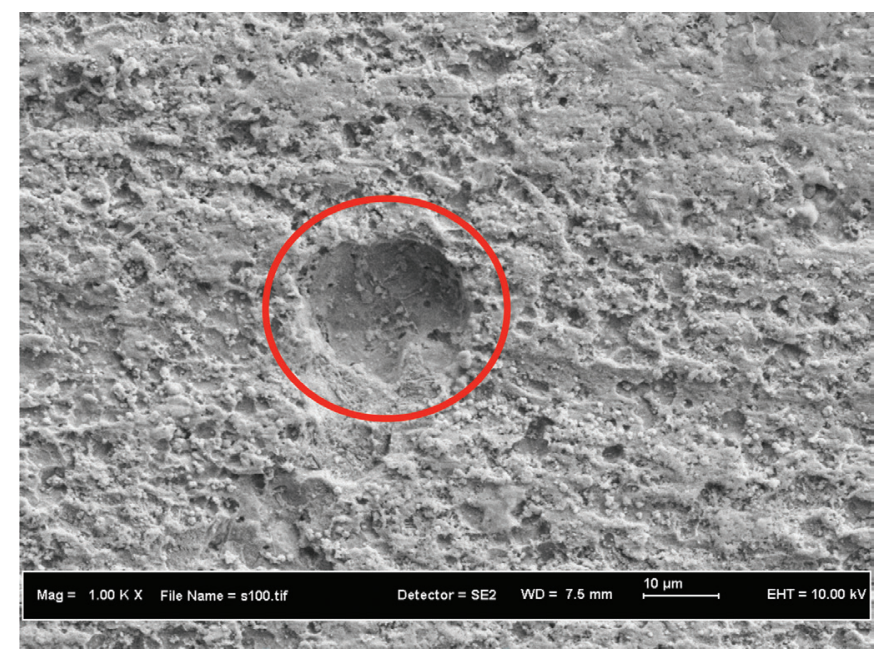

FIGURE 8. FESEM images for abiotic system on the coupon surface after biofilm was removed at different magnification at $1000 \times$ (rounded the pitting corrosion) 
Figure 10 shows the metal loss of the coupon steel after certain period of immersion in the media with SRB's presence. Coupons were retrieved on day-7, 14, 21 and 28 and their weights were recorded. The graph shows that there was no obvious discrepancy on the metal loss value under the UV exposure time periods of 3 and $30 \mathrm{~min}$ as compared to the abiotic samples. However, at $60 \mathrm{~min}$ of UV exposure, lower value of metal loss was noted throughout the 28 days of incubation and $0.0064 \mathrm{~g}$ difference of metal loss value was recorded on day- 28 compared to the abiotic system.

\section{INFLUENCE OF POWER OF UV LAMP FACTOR}

OFAT experiment procedure on UV treatment was repeated by switching the factorial to power of the UV lamp. Power here is defined as the rate at which energy is generated or consumed and hence is measured in units (watts) that represents the 'energy per unit in time' (EPA 1999). In this research, two different types of lamp with different power values were used in studying the influence on UV treatment on SRB's growth and metal loss. Figure 11 illustrates the growth pattern for SRB consortium for 28 days on biotic and abiotic systems. The time of exposure was fixed at 30 min for this experiment and UV treatment was done on day-3 of SRB seed incubation. From the graphical analysis, it was apparent that SRB growth had increased for abiotic system throughout the 28 days of incubation. In contrast, for biotic condition, the growth had started to decrease on day-7 to day-28. The turbidity differences of SRB growth between the biotic and abiotic samples were recorded at 0.625 abs (10 watts) and 0.695 abs (14 watts), respectively, at the end of the incubation days.

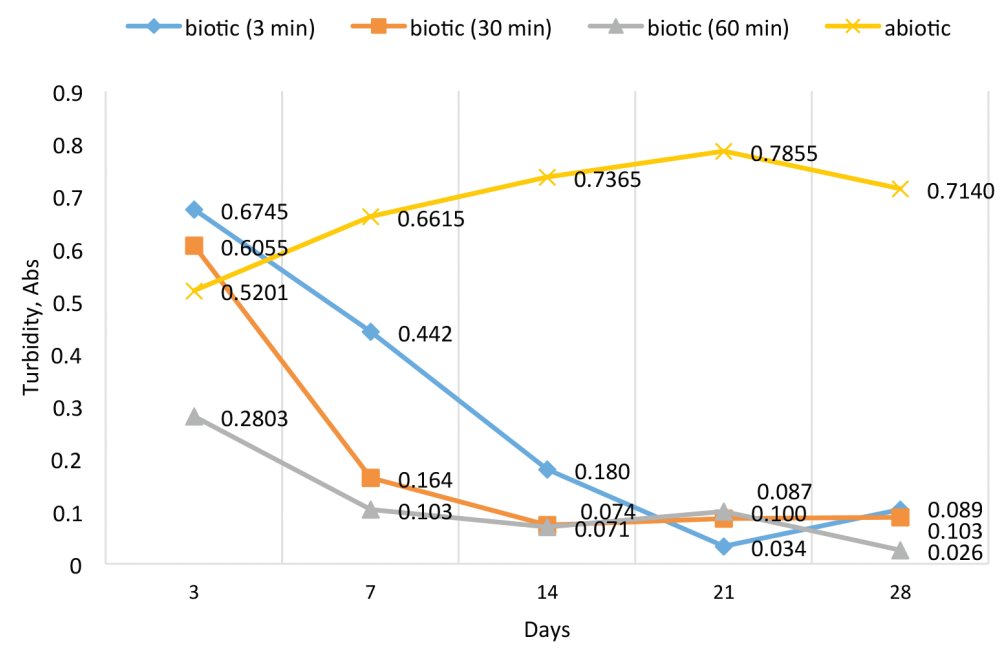

FIGURE 9. Turbidity over time (time factorial)

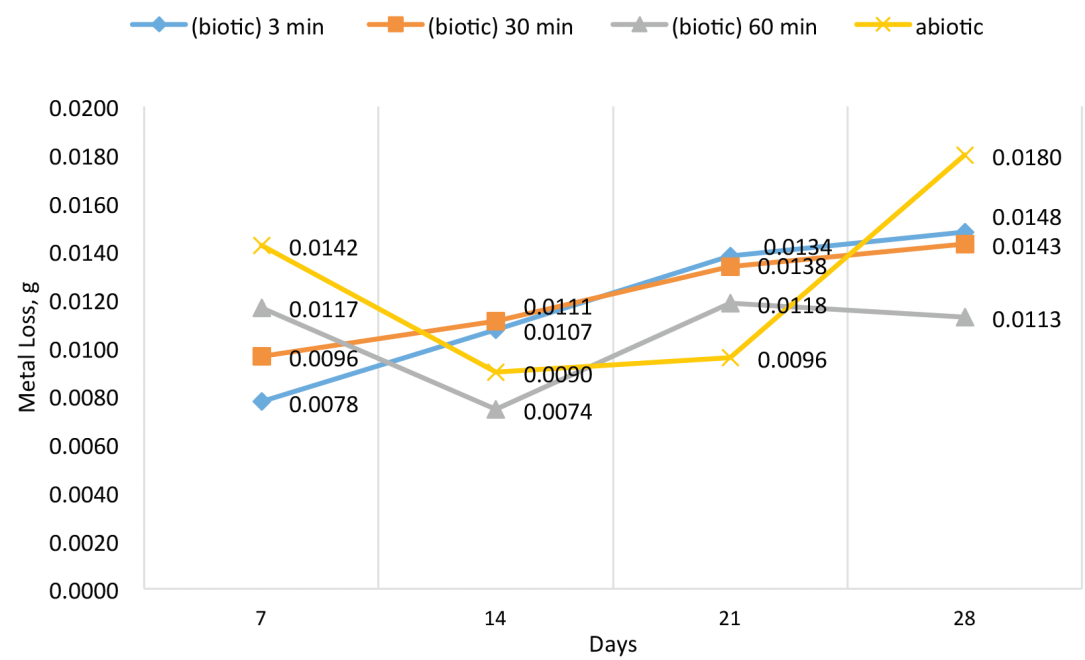

FIGURE 10. Metal loss over time (time factorial) 


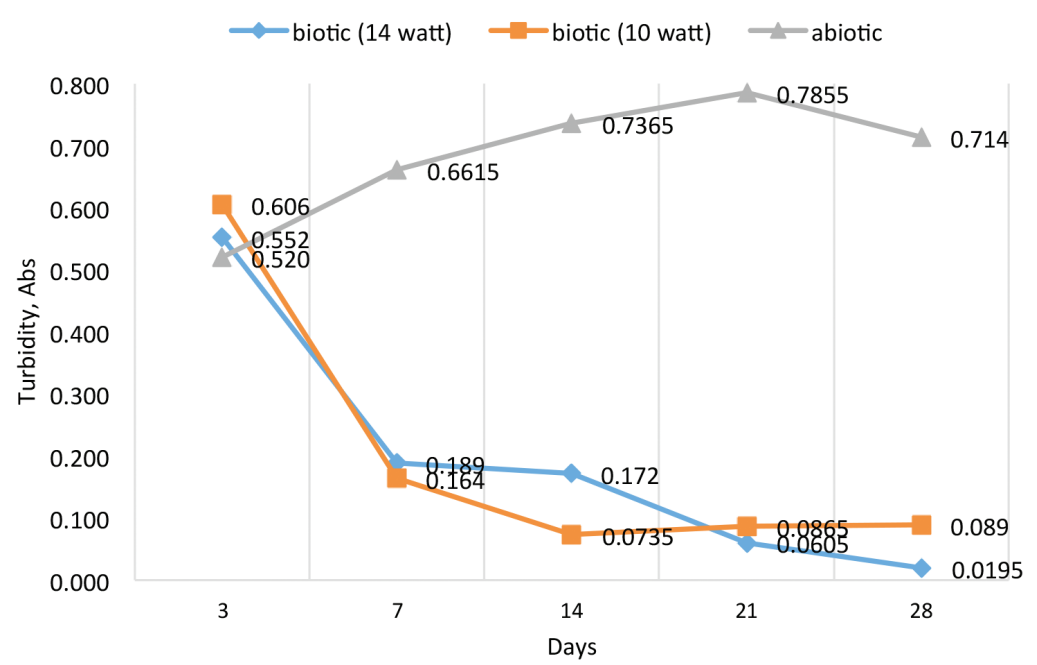

FIGURE 11. Turbidity over time (power of UV lamp factorial)

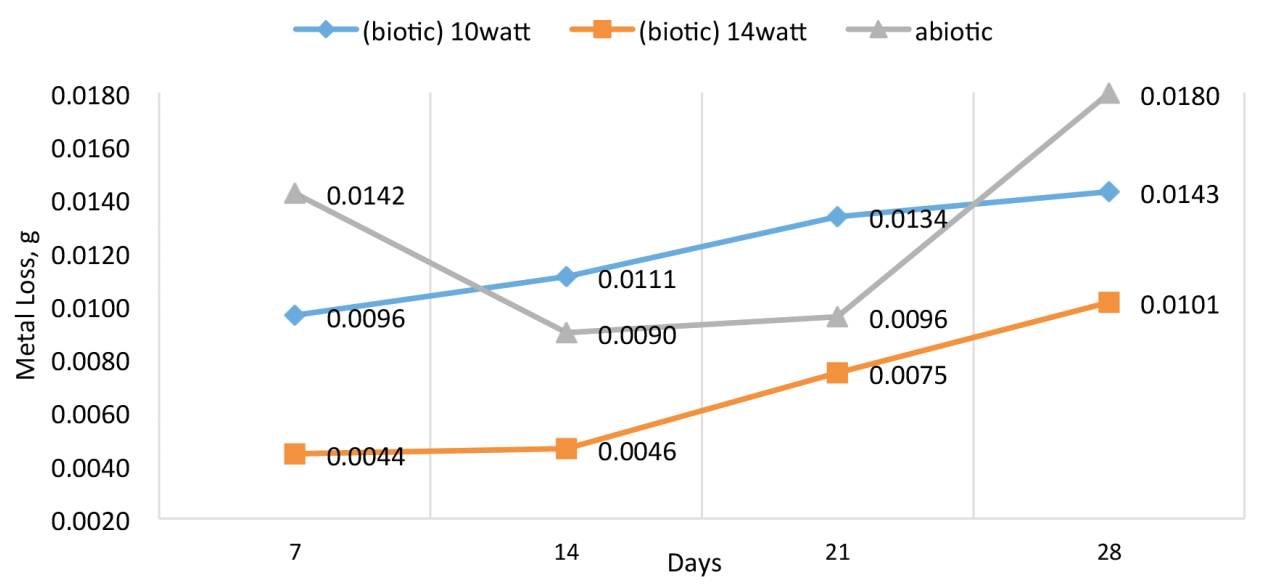

FIGURE 12. Metal loss vs days (power of UV lamp factorial)

Metal loss readings under the power of UV lamp factorial are presented in Figure 12. For exposure of UV lamp at 10 watts intensity, the trend shows slight decrease in the value of metal loss as compared to abiotic sample condition. Nevertheless, when the power of the UV lamp was replaced with 14 watts, it had reduced the metal loss to about $0.0079 \mathrm{~g}$ on day- 28 which is much lower than 10 watts samples. In summary, the impact of SRB existence to the carbon steel coupon could be minimize under the UV radiation exposure time period of below $30 \mathrm{~min}$ and with the UV power intensity at 14 watts based on the findings gathered.

It could be stipulated that by using UV radiation, biocorrosion caused by SRB can be kept marginal as compared to the untreated environment. However, turbidity of the medium produced by SRB activities could reduce the efficiency of UV treatment since UV radiation could not penetrate through all regions in the medium. Thus, mostly only planktonic bacteria could be exterminated during the treatment aside from sessile bacteria. That also explained even though the bacteria growth had decreased as proven in the turbidity test, the metal loss value could still be increased. Nevertheless, the results from the study also supported that the investigation of UV properties is crucial before any treatment could be implemented to ensure the optimum UV treatment effectiveness.

\section{CONCLUSION}

As the investigation outcomes shown, the UV exposure under the particular factorial could influence SRB's growth and metal loss rate of the carbon steel coupon. The evidence from this study also recommends cultivating the particular SRB consortium in Modified Baars media. FESEM image illustrated that the biofilm deposit manifested onto the coupon surface, indicating that after 21 days of its immersion in media with the presence of SRB, pitting corrosion had occurred. Elemental analysis with EDS detected ferum and sulphur-based corrosion products on both biotic and abiotic experimental systems. However, FESEM image subsequent to the treatment has 
not been performed, thus the UV radiation impact to the biofilm was not observed in this research. It must be emphasized that this analysis could be references or a guide to manufacturers and researchers in understanding the optimization of UV application in various industries.

\section{ACKNOWLEDGEMENTS}

The work was financially supported by Universiti Teknologi Malaysia (Grant No. GUP 03H49), Flagship (Grant No. 02G48) (Grant No. 02G44), the Ministry of Science and Technology, Malaysia, MOSTI (Grant No. Science Fund 4S019), Ministry of Education (MOE), Malaysia, (Grant No. ERGS 4L090) and Zamalah Institutional scholarship provided by Universiti Teknologi Malaysia.

\section{REFERENCES}

Abdullah, A., Yahaya, N., Noor, N.M. \& Rasol, R.M. 2014. Microbial corrosion of API 5L X70 carbon steel by ATCC 7757 and consortium of SRB. Journal of Chemistry 2014: Article ID. 130345. pp. 1-7.

Alabbas, F., Kakpovbia, A., Spear, J.R. \& Olson, D.L. 2012. Effects of sulfate reducing bacteria on the corrosion of X-65 pipeline carbon steel. Paper ID. C2012-0001140. NACE International. pp. 1-14.

AlAbbas, F.M. 2013. An investigation of microbial diversity in crude oil \& seawater injection system and microbiologically influenced corrosion (MIC) of linepipe steels under different exposure conditions. ProQuest Dissertations and Thesis. Thesis PhD. Colorado School of Mines (Unpublished).

Allison, P.W., Clough, D., Park, B., Vance, I. \& Thompson, M.J. 2008. The investigation of microbial activity in an offshore oil production pipeline system and the development of strategies to manage the potential for microbially influenced corrosion. Paper No. 08651. Nace International Corrosion Conference and Expo. pp. 1-17.

Almahamedh, H.H., Spear, J.R., Olson, D.L., Williamson, C. \& Mishra, B. 2011. Identification of microorganisms and their effects on corrosion of carbon steels pipelines. Paper No. 11231. Nace International Corrosion Conference and Expo. Houston, TX. pp. 1-11.

Beavers, J.A. \& Thompson, N.G. 2006. External corrosion of oil and natural gas pipelines. ASM Handbook. Corrosion: Environments and Industries 13C: 1015-1026.

Chang, Y.J., Chang, Y.T., Hung, C.H., Lee, J.W., Liao, H.M. \& Chou, H.L. 2014. Microbial community analysis of anaerobic bio-corrosion in different ORP profiles. International Biodeterioration \& Biodegradation 95: 93-101.

Chang, Y.J., Hung, C.H., Lee, J.W., Chang, Y.T., Lin, F.Y. \& Chuang, C.J. 2015. A study of microbial population dynamics associated with corrosion rates influenced by corrosion control materials. International Biodeterioration \& Biodegradation 102: 330-338.

Cheung, C.W.S., Beech, I.B., Campbell, S.A., Satherley, J. \& Schiffrin, D.J. 1995. The effect of industrial biocides on sulphate-reducing bacteria under high pressure. International Biodeterioration \& Biodegradation 33(4): 299-310.

Clark, J.B., Luppens, J.C., Co, P., Tucker, P.T. \& Petru, P. 1984. Using ultraviolet radiation for controlling sulfate-reducing bacteria in injection water. Paper ID. 13245. 59th Annual Technical Conference and Exhibition. Texas.
Comanescu, I., Taxen, C. \& Melchers, R.E. 2012. Assessment of mic in carbon steel water injection pipelines. Paper No. 155199. Society of Petroleum Engineers - SPE International Conference and Exhibition on Oilfield Corrosion. pp. 227234.

Gloe, L., Neal, G. \& Kleinwolterink, K. 2010. Ultraviolet light disinfection of fracturing fluids. Proceedings of SPE International Health, Safety and Environmental Conference. pp. 1-7.

Ismail, M., Noor, N.M., Yahaya, N., Abdullah, A., Rasol, R.M. \& A. Rashid, A.S. 2014. Effect of $\mathrm{pH}$ and temperature on corrosion of steel subject to sulfate reducing bacteria. Journal of Environmental Science and Technology 7(4): 209-217.

Javaherdashti, R. 2008. Microbiologically Influenced Corrosion. An Engineering Insight. Verlag London Limited. New York: Springer. pp. 29-71.

Lawal, O., Shannon, K., Gloe, L., King, K., Warren, W., Hargy, T. \& Fong, F. 2010. Ultraviolet disinfection effectively controls oilfield sulfate reducing bacteria. IUVA News, September. pp. 17-20.

Little, B.J. \& Lee, J.S. 2009. Microbiologically influenced corrosion. Kirk-Othmer Encyclopedia of Chemical Technology. New York: John Wiley \& Sons, Inc.

Maxwell, S. 2005. Controlling corrosive biofilms by the application of biocides. Paper ID. SPE93172. SPE International Symposium on Oilfield Corrosion. pp. 1-8.

Maxwell, S. \& Campbell, S. 2006. Monitoring the mitigation of MIC risk in pipelines. Paper No. 06662. Corrosion NACE Expo, 61st Annual Conference \& Exposition. pp. 1-16.

McKinney, C.W. \& Pruden, A. 2012. Ultraviolet disinfection of antibiotic resistant bacteria and their antibiotic resistance genes in water and wastewater. Environ.Sci.Technol.46(24): 13393-13400.

Melchers, R.E. \& Jeffrey, R.J. 2008. Probabilistic models for steel corrosion loss and pitting of marine infrastructure. Reliability Engineering \& System Safety 93(3): 423-432.

Sarioğlu, F., Javaherdashti, R. \& Aksöz, N. 1997. Corrosion of a drilling pipe steel in an environment containing sulphatereducing bacteria. International Journal of Pressure Vessels and Piping 73(2): 127-131.

Wang, J., Yang, F., Yuan, X., Liu, B., Wu, H. \& Sui, X. 2005. Successfully sterilizing the sulfate bacteria with ultraviolet radiation in produced-water treatment in daqing oilfield. Paper ID. SPE 93148. Asia Pacific Oil \& Gas Conference and Exhibition.

Faculty of Civil Engineering

Universiti Teknologi Malaysia

81310 UTM Johor, Johor Darul Takzim

Malaysia

*Corresponding author; email: norhazilan@utm.my

Received: 3 July 2016

Accepted: 23 January 2017 